\title{
A Study on the Application of Nonverbal Communication in Cross-Cultural Business Negotiation
}

\author{
HE Bei-bei \\ Ningbo Dahongying University, Ningbo, China
}

\begin{abstract}
Generally speaking, human communication has two ways: verbal communication and nonverbal communication. People usually pay more attention to the verbal communication and neglect the nonverbal communication. With the development of the society, people have more chances to communicate with people from other nations. Since different nonverbal behaviors have different meanings in different cultures, conflicts are unavoidable. Nonverbal communication is attracting more and more peoples' attention. The author makes an analysis of the application of nonverbal communication in cross-cultural business negotiation as to help businessmen to improve the efficiency in cross-cultural business negotiation and achieve success in cross-cultural business.
\end{abstract}

Keywords: application, nonverbal communication, cross-cultural business, negotiation

\section{Introduction}

In the process of globalization, with the rapid growth of international economies, people from different parts of the world are contacting more intimately, cross-cultural business contacts are becoming frequently. In cross-cultural business, businessmen need to negotiate. Negotiation is crucial to cross-cultural business. In cross-cultural business negotiation, verbal communication and nonverbal communication are found to be indivisible. But when people talk about negotiation, more attention is being paid to the verbal communication while the nonverbal communication is often neglected. Nevertheless, nonverbal communication plays an irreplaceable role in cross-cultural negotiation as it has the function which cannot be realized by verbal communication in some situations. A clear understanding of people's nonverbal communication is beneficial to the process of the cross-cultural business negotiation.

Compared with verbal communication, the research on nonverbal communication is quite limited. There are not so many books related to it. But the application of nonverbal communication cannot be ignored. According to Samovar's perspective, $65 \%$ of people's communication is formed by nonverbal communication. Nonverbal communication can be divided into four parts: body language, paralanguage, objective language, and environmental language. The application of these four parts is highly related to the result of negotiation in cross-cultural business.

\section{A Brief Introduction of Nonverbal Communication}

\section{Definition and Classification of Nonverbal Communication}

Up to now, the definition of nonverbal communication has been explained by many researches. But these

HE Bei-bei, undergraduate, College of Humanities, Ningbo Dahongying University. 
definitions are different from each other because their focuses are varied. According to the Wikipedia, nonverbal communication means the communication without words. According to other definitions and explanations, nonverbal communication means all aspects of a message which are not conveyed by the oral or literal words. In other words, it conveys by other medium. People usually divided nonverbal communication into four parts: body language, paralanguage, objective language, and environmental language. Body language refers to the body movements, including postures, gestures, facial expressions, eye contact, and touching. Paralanguage includes pitch, rate, volume, specific sounds, silence, and pause. Environment language is about the proxemics and time. Object language includes dressing, appearance, and body odor.

\section{Functions of Nonverbal Communication}

M. J. Hickson and D. W. Stacks did a lot of researches on nonverbal communication. As for the functions of nonverbal communication, they agreed that nonverbal communication has six primary functions in conjunction with the verbal communication: (1) repeating: Repeating can emphasize or stress the verbal message; (2) complementing: Complementing is similar to repeating; (3) substituting: Nonverbal communication have meaning which words do not carry; (4) regulating: Regulation helps to coordinate the verbal communication between people; (5) contradicting: Nonverbal communication will send meanings opposite from the verbal communication; and (6) accenting: Accenting can emphasize the particular point in the verbal communication.

\section{Application of Nonverbal Communication in Cross-Cultural Business Negotiation}

In cross-cultural business negotiation, people who are from different nations get together to do business, so this part will analyze the applications of nonverbal communication by some real cases. All of these cases are from real business contacts. These cases can ensure the authenticity and persuasiveness.

\section{Application of Body Language in Cross-Cultural Business Negotiation}

Body language refers to the body movements, mainly including posture, gesture, facial expression, eye contact, and touch. In today's cross-cultural business negotiation, a lot of conflicts are caused by the misunderstanding of body language. In the following case the application of gesture will be analyzed.

Case 1:

A British businessman once did business with an Iranian businessman, after months of negotiations, two sides agreed to sign the contract. The British businessman turned to the Iranian partner and made a thumb up while they began to sign the formal contract. This gesture caused a sensation immediately, the Iranian businessman left with anger immediately. In this case, the causes of conflict is quite simple: Thumbs up means said "good, well, well-done, do good" in the United Kingdom, but in Iranian culture, it means "unsatisfactory" or even "dirty". (CAO, 2007)

From this case, people should note that the meaning a body language conveys is different in different nations. Identifying body language and different meanings in body language is an art. Good businessmen have to know how to use body language and how to read other people's body language to gain the advantage. To some extent, culture determines the body language people use to express their inner world. In cross-cultural business negotiation, the conflicts of nonverbal communication mistakes sometimes can cause more serious consequences than verbal communication mistakes. 


\section{Application of Paralanguage in Cross-Cultural Business Negotiation}

Paralanguage includes pitch, rate, volume, specific sounds, silence, and pause. Many businessmen benefit a lot by applying the paralanguage in their negotiation. In the following case, the application of silence will be analyzed.

Case 2:

An American company was negotiating with a Japanese company. The American businessmen first quoted a price for the production. The Japanese businessmen keep silent for more than three minutes in accordance with their customs. The American businessmen felt uncomfortable and frustrated with silence. Finally, the American businessmen could not put up with the silence and lowered the price. In fact, the Japanese businessmen could accept the original price. However, Americans didn't know the meaning of silent and made compromise. (FU, 2012)

For many Asian businessmen, silence is often used as a means of avoiding conflict. Sometimes people will cover the inner world by silence. This practice is typical for Asians. However, in America, people regard silent reaction as a negative reaction. Americans are uncomfortable with silence. If they experience a long silence, they will feel great uneasiness. From this case, people can note that silence as one of the nonverbal communications makes the negotiation unpredictable in some situation. In cross-culture business, the application of paralanguage cannot be ignored.

\section{Application of Objective Language in Cross-Cultural Business Negotiation}

Object language mainly includes dressing, appearance, and body odor. Object language as a nonverbal communication can present one's culture and personality. In the following case, the application of dressing will be analyzed.

Case 3:

Two businessmen from the United States were waiting in an office for foreign trade in Germany. A businessman entered, obviously waiting for an appointment too. The newcomer dressed casually. Without having spoken to the businessman, the two businessmen looked at each other and agreed, the newcomer was an American. How did they learn? The style of the suit was clear signals. They were right, the newcomer was American. (LI, 2012)

In cross-cultural business negotiation, nearly all businessmen wear suit, Americans dress casually; however, in countries like England, businessmen pay more attention to the formality of dress. European businessmen usually wear suits that are more tailored. Generally speaking, in the cross-cultural business, businessmen should dress in a decent way. A formal dressing shows the respect for others. At the same time, what the businessmen choose to wear conveys the nonverbal communication about their culture and personality. Dressing as a visible nonverbal communication, people need to pay attention to the difference in it and respect different cultural practices.

\section{Application of Environmental Language in Cross-Cultural Business Negotiation}

Environmental language, as another nonverbal communication, plays an important role in cross-cultural business negotiation. Environmental language includes proxemics and time. In the following case, the application of time will be analyzed.

Case 4:

A Mexican company wanted to buy new equipment from a German company. The German businessmen arrived on time. They waited for the businessmen from Mexico fifteen minutes. But the businessmen from Mexico still did not appear or give a call to apologize to the Germans. The Germans felt impatient but they still waited for the Mexican negotiators. At 
last, the negotiators from Mexico arrived almost an hour later. Mexicans made the Germans quite angry. The Germans said the Mexicans were too impolite. Mexicans admitted they were later than the time as planned, but they think it was acceptable. Finally, this business negotiation failed. (FU, 2012)

In this case, people can easily know that the real reason for their conflicts is that they have different time orientations. Before negotiation, they did not learn each other's culture. Germans are always punctual, while Mexicans are habitually late. Edward T. Hall points out the lead times are different in different countries. In some nations, people need to plan important appointment at least two weeks in advance. Americans often say that time is money. Their time orientation also reflects their concept of efficiency. In cross-cultural business negotiation, a clear understanding the nation's time orientation is helpful to improve result of negotiation.

\section{Suggestions for Using Nonverbal Communication in Cross-Cultural Business Negotiation}

In the above chapters, the author has an analysis on the applications of nonverbal communication and how these nonverbal communications influence the cross-cultural business negotiations. In this chapter, the author will put forward some feasible suggestions in improving the application of nonverbal communication in cross-cultural business negotiation.

In cross-cultural business negotiations, first of all, businessmen should always bear in mind that culture is never invariable. Businessmen should be cautious and open-minded to other cultures. Nonverbal communications habits are quite different from nation to nation. In different cultures, people will use different nonverbal communication to express the same meaning, because their understanding to nonverbal communication is different. Secondly, businessmen need to engage in cross-cultural business as much time as possible. Through cross-cultural business, businessmen will have a more clear understanding of the application nonverbal communication. That requires people who engage in cross-cultural business negotiation spend as much time as possible to communicate with people from different culture. Thirdly, people's understandings of the situation where they are involved can also influence the application of nonverbal communication. Negotiators should hold tolerant and considerable attitude towards foreign nonverbal communication and respect other countries' cultures. Thus, negotiators should "do as Romans do" and respect the other countries' nonverbal communications.

To conclude, when people want to make use of nonverbal communication better, first of all, they should attach importance to the difference of nonverbal communication in cross-cultural business. Secondly, cross to understand nonverbal communication in other cultures. Third, understand other countries' nonverbal communications and use nonverbal communications accepted by both sides.

\section{Conclusion}

Cross-cultural business negotiation is playing a more and more important role in the cross-cultural trade in today's world. In the cross-cultural business negotiation, people have two main modes of communication, verbal and nonverbal. In cross-cultural business, culture affects how people communicate and behave. Culture influences the way people negotiate as well. The study of nonverbal communication is very necessary in cross-cultural business negotiation. Based on nonverbal communication theory and analytic method, the author analyzes the application of the nonverbal communication in cross-cultural business negotiation. The analytical study is based on the cases in cross-cultural business negotiation. The aim of this thesis is to help businessmen to understand the application of nonverbal communication better and improve the effectiveness in 
cross-cultural business negotiation. This thesis also gives some flexible and practical suggestions to those who engage in the cross-cultural business negotiations to reduce nonverbal conflicts and improve the efficiency in cross-cultural business negotiation.

\section{References}

BI, J. W. (1999). 跨文化非语言交际 (Nonverbal communication in cross-cultural communication). Beijing: Foreign Language Teaching and Research Press.

CAO, P. S. (2007). 国际商务谈判中的非语言交际探析 (An analysis on nonverbal communication in international business negotiation). Market Modernization ,6, 49-50.

FU, X. C. (2012). 国际商务谈判中非语言交际研究 (A study on nonverbal communication in international business negotiation). Tianjin: Tianjin University of Finance and Economics.

GAO, Y. L. (2007). 非语言交际在跨文化商务交际中的功能及运用 (Functions and applications of nonverbal communications in intercultural business communication settings). Shanghai: Shanghai International Studies University.

Hall, E. T. (1959). The silent language. New York: Doubleday.

Hickson, M. J., \& Stacks, D. W. (1985). Nonverbal communication: Studies and applications. Lowa: Wm. C. Brown Publishers.

LI, X. J. (2012). 非语言交际在跨文化商务谈判中的应用研究 (A study on the application of nonverbal communication in cross-cultural business negotiation). Northeast: Northeast Forestry University.

Samovar, L. A., Porter, R. E., \& Stefani, L. A. (1997). Communication between cultures. New York: Wadsworth Pub Co.. 